\title{
EMPOWERING POSTGRADUATE STUDENTS THROUGH ONLINE CAREER MENTORING
}

\author{
Ellis RUBINSTEIN \\ Editor, Science
}

(This paper was originally presented at the "Post-Graduate Education in Europe: Past-Present and Future Conference" arranged by The National Agency for Higher Education in Sweden at Linköping University between 4-5 May 2001.)

Abstract: Many of today's postgrads and postdocs-be they in the United States or in Europe-are interested in exploring the widest possible range of scientific career options, everything from positions in academia and industry to careers 'off-thebench'. But too often, they don't know where to start, and, at the same time, lack knowledgeable mentors. Moreover, the pace of change within the scientific profession is accelerating. Suddenly, the benefits of multi-disciplinary career paths, mobility, and global collaborations outweigh their costs in complexity. Many university systems are coming to recognize this but are struggling to reform their traditional systems. And the pace of these changes threatens to outstrip the ability of administrators and faculty to keep current with new needs. In this environment, Science's Next Wave provides a broad array of novel services while achieving economies of scale for subscribing institutions. Each week, Next Wave publishes online original articles providing career advice to young scientists and those who would mentor them. Over its 6 years of existence, the Next Wave website has developed an unmatched, living archive of information on career planning, job hunting, grant-writing, education reform, and much more. And it has become increasingly global, going beyond its starting point in the U.S. to develop collaborations with panEuropean organizations and national bodies. For example, it is partnering with China's national organizations and has established homepages in the UK, Canada, and Germany. Next to join: the Netherlands and Singapore.

\section{PROLOGUE: THE CHALLENGE FOR GRADUATE EDUCATION}

In Sweden in the fall of 1999 , the organization responsible for graduate education, the Hogskoleverket, commissioned a small study of the needs of graduate students in a variety of disciplines-from science and math to the humanities. Following the holding of a series of focus groups around the country, the Hogskoleverket reported the following views of graduate students studying in Sweden:

- A large majority think departments should, to a much larger extent than today, inform and prepare Ph.D. students so that they will have an overview of the range of possibilities of an academic career, as well as providing knowledge about industry and managerial positions. "Universities have managed to grow ivory towers with too few global contacts," [said some, and] "Universities isolate themselves from industry..." [Said others].

- Only $20 \%$ claim that they get career planning help from their departments... and often the supervisor wants the student to continue in his/her research group as a postdoc.

- After many years in research and education, many supervisors are not aware of the legal and economic elements of today's [non-academic] careers.

- Because their supervisors write grant applications [in isolation], graduating Ph.D. students are unprepared for this...

- Family issues are especially bothersome [and no one is helping with these].

- Only $10 \%$ of those interviewed were helped in making contacts in the labor market.

- Ph.D. students with foreign backgrounds find it 'strange' that internationalization of research and the establishment of foreign contacts are not appreciated in Sweden's universities.

Are such concerns among graduate students unique to Sweden? Of course not. Here are some remarks made by observers of the conditions of graduate life in other European countries:

From an article in Science, 10 November, 2000, by Kai Simons and Carol Featherstone, of EMBL: "There are too many scientists working in isolation under depressing conditions in the many European universities. Molecular life scientists across the breadth of the new Europe must feel included in the scientific community, especially the new generation of young and active scientists who will build the scientific Europe of the 21st century. Because science should not and does not have national borders, 
these young scientists will be a spearhead for collaboration in a wider sense in Europe."

From a 1999 report by French Deputies Pierre Cohen and Jean-Yves Le Déaut, as reported in Science (30 July, 1999): "...although French research has remarkable potential, it faces serious problems... First, researchers rarely move between universities, industry, and public research agencies such as the basic science agency CNRS. Second, young scientists have great difficulty finding research jobs and achieving scientific independence."

From remarks made to Science (4 June 2000) by materials scientist Richard Brook, chief executive of the U.K.'s Engineering and Physical Sciences Research Council, who chaired a blue-ribbon panel commissioned by the German government: "Young researchers should be encouraged to do independent work more quickly than they do now in the German system. The Habilitation means you can be 40 years old before you find out whether you have an academic career ahead of you."

Should any of this be surprising? Not to Europeans who have followed the debates about the need for a European research area, as proposed by European Commission Research Director Phillippe Busquin or the speeches by Germany's Minister of Science and Education Edelgard Bulmahn. And I could name others who are deeply concerned about Europe's competitiveness, its treatment of young scientists, and its ability to recruit and retain new young scientists. Indeed, this is why, across Europe there are movements, both national and multinational, to reform graduate education, to boost funding, to foster competitiveness and excellence and so much more. Hence, the meeting that brings us all here today.

\section{NEXT WAVE: ONE ANSWER TO THE CHALLENGE}

So if we all know the scope of the challenge, how does one mount a viable, scalable response to the challenge? Traditionally, reforms are carried out through traditional institutions. Thus, in addressing the $21 \mathrm{st}$ century needs of graduate students, blue-ribbon panels in Europe and the United States have recommended actions that could be taken by both executive and legislative branches and by individual universities themselves. But the limitations of this traditional approach to a problem is that help to the individual depends on the speed of response by often ponderous bureaucracies, the filtering down of reform from administrations to individual departments, and the capacity of faculty members to actually behave in new ways.
The young American physicists who, in 1994 and 1995 , found themselves in 2 nd and 3 rd postdocs with no prospects for traditional academic positions and no assistance from their mentors to develop novel approaches to their career needs weren't about to wait for a traditional response to their problem. Identifying the Internet as a medium that might allow, at remarkably low cost, large numbers of young people to be helped-all at the same time-without respect to the capacities of their home institutions and personal mentors, these young physicists started a web page called the Young Scientists' Network. Their notion; self-help through virtual networking.

\section{THE BIRTH OF NEXT WAVE}

At Science, this movement was not lost on a few of the editors. It was our view that there were both strengths and weaknesses in the approach of the young physicists. Among the strengths was the fact that a lively "webzine" could create a community of common interest that could bridge the isolation that had been devastating U.S. postgraduate students who were bereft of career advice from competent mentors. The weaknesses were threefold, at least. First, the singular focus on physics made no sense when the same trends and issues were evident-or likely to become so-in many scientific disciplines and when the answer for some physicists would lie in other disciplines. In fact, the solutions for many young people would clearly often be in multi- or transdisciplinary careers, making it more difficult for any single group or professional society to highlight them. And, finally, there was the question of whether a leaderless group of young people, operating without any institutional base, could maintain a webzine for very long.

Science is owned by the American Association for the Advancement of Science (AAAS)-an umbrella organization covering all disciplines and chartered to help the scientific community. Based on the unique AAAS charter, it seemed natural to us at Science to consider trying to help these young physicists and all the young chemists, biologists and so forth who would have common concerns. And because one could imagine launching a website without encountering the enormous embedded costs of traditional print media, we were able to convince the heads of our not-for-profit organization to let us launch a pan-scientific website addressed exclusively to the career needs of all young scientists.

\section{WHAT THE NEXT WAVE DOES}

That was in 1995. In the years since-and with the support of some extraordinary foundations, government agencies, and scientific leaders-the Next Wave has expanded to address many of the needs identified by the graduate students in Sweden. Here is a brief tour of some 
primary functions now being performed by the Next Wave in support of the career needs of young people:

- Job Market News: What does today's job market offer scientists interested in making their next move? From biomedical funding news to enrollment statistics, we investigate employment trends, how to make oneself eligible for today's positions, and national and international opportunities.

- Career Transitions I.-Alternate Careers: Research not for you? There is a constant flux of researchers into and out of the science community, and in this section we describe some of the notably successful, nontraditional career moves researchers have made. Examples? Leaving the bench to get an MBA, going into marketing and business, applying one's research skills to work with the police as a forensic scientist or becoming a teacher. Other alternate careers we have featured include: Intellectual Property, Management Consulting, Pharmacoeconomics, Regulatory Affairs, Research Program Management, Science Journalism, Science Policy, Technology Transfer.

- Career Transitions II.-New Research Directions: Sometimes someone just needs to get out of the niche they are in and move into something hotter or more rewarding. We provide first-hand experience and advice in areas like: Bioinformatics, Clinical Trials, Computer Modeling, Nanotechnology, Proteomics, Environmental Science, and many more.

- Career Development Center: Getting to the end of a Ph.D. can be a tough slog! And all through what may be a 5-, 6- or 7-year search for a doctorate or its equivalent, many young scientists never learn how to deal with administrators, file progress reports, develop budgets, fill out fellowship applications, set up their first laboratories or write better grant proposals. This section provides advice on all that.

- Postdoc Network: This newest area of the website provides real-world solutions to the career and quality of life needs of postdoctoral scientists. Original content addresses benefits, career programming, creating a postdoc office, and more. Additionally, the Postdoc Network includes a database of institutions with postdoc offices or associations and a listserv to help these groups connect.

And the list could go on! For example, the Next Wave offers America's most extensive database of training grants in the biomedical sciences and articles and online forums on family issues and the problems women and minorities face. In the articles and forums, the discussants are either young scientists who have faced similar problems and found a way to overcome them or senior advisors who have lots of wisdom to dispense.

\section{THE REPONSE TO NEXT WAVE}

For all these reasons, the Next Wave has become a resource that could neither be duplicated by any individual career center at a single institution, nor easily reinvented by national and transnational bodies. It may come as no surprise to hear that it has succeeded in the United States both in usage and financially. In terms of usage, we are being visited by more than 25,000 unique computers per month in the United States alone. In fact, in only 3 years nearly 90,000 scientists have registered to use our grants service. And during the year 2000, about 200,000 unique computers visited Next Wave worldwide. When one thinks about how many different people might use a computer in a university setting, the number of scientists using our site over a year's period may easily double the circulation of Science magazine, which has itself three times more subscribers than any other general scientific journal.

As for the Next Wave's financial success in the United States, national agencies including the National Institutes of Health, the Department of Energy, and National Aeronautics and Space Agency have subscribed to it for their scientists. Renowned private foundations such as the Howard Hughes Medical Institute, the Burroughs Wellcome Fund, the Sloan Foundation, and, soon, the Packard Foundation, have given it grants to expand its services to the scientific community. And over 125 research universities (including the entire Ivy League, the Big Ten, and most of the University of California system)-_plus health centers and hospitals, independent research laboratories, and even 10 prestigious professional societies such as the American Chemical Society and the American Physical Society-have all purchased subscriptions for their constituents.

Gradually, too, leaders in countries outside the U.S. have come across the Next Wave with many choosing to create national collaborations with the website in order to bring its unique content to their constituencies. Among these, in the UK there have been Sir Robert May, now the President of the UK Royal Society but previously Science Advisor to the UK government, and Lord Sainsbury, Minister of Trade and Industry. Dr. May has written: "The scientific community has no higher responsibility than the mentoring of its next generation. Science's Next Wave is meeting this challenge with remarkable effectiveness." UK Science Minister Lord Sainsbury added: "Britain's young scientists are a unique national resource and Next Wave are helping towards nurturing and developing their talents." 
In Canada, the past and current Presidents of the Canadian Institutes for Health Research (previously the Medical Research Council) have taken subscriptions for the entire nation and supported the hiring of an editor in that country. In Germany, the President and Secretary General of the Deutsche Forschungsgemeinschaft have both been major supporters of a German involvement. President Ernst-Ludwig Winnacker has written: "The support of the scientific new generation is an urgent function of the German research council. The DFG strongly supports therefore the efforts of Science's NEXT Wave to improve the dialog among young scientists beyond narrow subject disciplines and geographical boundaries."

Finally, in China, the President of the National Natural Science Foundation and the Minister of Science and Technology have made it possible through a grant to bring the Next Wave at no cost to all scientists able to access the Internet. Considering the sensitivity of the nation's leadership to online interactions between their students and those in the West, this provision of free access is truly a stirring endorsement of the value of the Next Wave's career advice.

In summary, for 4 years, national bodies - and one multinational corporation, Merck-in Canada, the UK, China, and Germany have joined the U.S. in supporting the Next Wave. These nations' prestigious institutions support some or all of the following:

(1) The salary and fringe benefits of a Next Wave Editor in their country

(2) The creation of a national homepage that highlights career information of direct value to their nationals

(3) Funding of outreach events-such as career seminars-at universities and professional society venues as well as promotion of the Next Wave throughout their nation's academic and government research infrastructure

(4) National subscriptions to support free access for all young scientists employed in not-for-profit academic and government research institutions.

In addition, the Next Wave has now established collaborations with Singapore and with the European Molecular Biology Organization, and the Marie Curie Fellowships. We hope to soon sign an agreement with the Netherlands' NOW and are in discussions with the ESF and EC.

\section{NEXT WAVE'S FUTURE}

Despite this success, the Next Wave has much to do. We are concerned, for example, that our need to establish national subscriptions to achieve financial independence has inevitably created an unfortunate barrier for those whose nations or academic institutions lack vision or money. We loathe the notion that the Next Wave may unwillingly be yet another excellent example of dangers of the Digital Divide.

Notably, the heaviest users of the Next Waveeven among its loyal subscribers - are the students who one might think would need advice the least. Thus, universities like Harvard, Stanford, Johns Hopkins, Toronto, McGill, and Cambridge have the largest per capita portion of their computers visiting the Next Wave. A close look at who has not subscribed to the Next Wave in the U.S. - or who is using it least in subscribing countries outside the U.S.-will complete the depressing picture.

So the Next Wave team has invested int the creation of a group of staff members charged to ensure that students at smaller or more remote universities know about the advice we offer. This promotion team has developed a valuable database of the key career offices, deans, and vice provosts of research at each subscribing institution. And it is gradually building a network of volunteer campus representatives. Each month, e-mail alerts go to these people, requesting that they spread the word of what we are offering. If after several months, usage has not increased at such institutions, our staff will even conduct campus visits, providing seminars and career days after which usage invariably rises to new levels and remains there.

But this does not solve the concern-oft voiced by European leaders - that the smaller European nationsespecially those in East Europe-have not discovered the Next Wave, thereby preventing their students from accessing information enjoyed by their more fortunate peers in the UK, Germany, and soon in the Netherlands. Nor does it address the concern of others that students in the Developing World cannot access all of our best materials.

Based on the concerns voiced in Europe, Next Wave staffers have opened conversations with the European Commission and the European Science Foundation. With respect to developing nations, we would need a partner like UNESCO-a target for our future. 
Finally, many in the United States and in Europe have observed that undergraduates would benefit extraordinarily from a website that uses the same modelarticles authored by a mix of role models and experts - to provide advice focused on issues and concerns particular to undergrads. Based on these entreaties, the Next Wave has secured funding from the prestigious Packard Foundation to create a prototype portal for undergraduates from minority backgrounds. Once commenced, this portal should become a model for an expansion of services to undergraduates in general-a development many in the scientific community would like to see.

One question for this audience would be: How badly would European undergraduates need such a service? I would be interested in reactions to this thought.

And the venue of this meeting suggests an even more important, overarching question: In what ways might the Next Wave-as it already exists and as it could be expanded-serve the goals of the Sixth Framework Program with particular respect to the desire to enhance mobility and to empower Europe's young scientists to stay in Europe and yet compete more effectively with their peers in the U.S.? Perhaps this too could yield an interesting dialogue between us.

And, lastly, I cannot help but ask this audience to consider the many ways in which more European content-and more European wisdom-might enhance and improve the Next Wave's American homepage. Americans are famously insular and badly need to know about the very special opportunities Europe can provide.

I have previously pointed out that the Next Wave is owned by a not-for-profit organization-the American Association for the Advancement of Science. The AAAS charter calls on it to serve the scientific community not merely in the U.S. but throughout the world. As a not-forprofit, the AAAS lacks the resources that large multinational STM (science, technology, and medicine) publishers could bring to bear on developing novel online services for the scientific community. But this can be a blessing and not a curse if it motivates the AAAS to partner with not-for-profit NGOs and national government organizations with like-minded goals. This is in fact what has caused Next Wave to thrive. So based on this successful model, I come to this meeting with the hope of discovering like-minded visionaries interested in developing win-win opportunities in the service of our various constituencies. Perhaps we can, together, develop an unprecedented global resource of career advice and mentoring that would empower the next generation of scientists. 